\title{
SHALLOW SEISMIC REFLECTION SURVEY FOR IMAGING DEEP-SEATED COAL LAYER - CASE STUDY FROM MUARA ENIM COAL
}

\author{
SURVEI SEISMIK REFLEKSI DANGKAL UNTUK \\ MENGGAMBARKAN LAPISAN BATUBARA BAWAH \\ PERMUKAAN - STUDI KASUS BATUBARA MUARA ENIM
}

\author{
MUHAMMAD R. RAMDHANI*, MUHAMMAD A. IBRAHIM, HANS E. A. SIREGAR and \\ TONY RAHADINATA \\ Center for Mineral, Coal and Geothermal Resources, \\ Geological Agency, Ministry of Energy and Mineral Resources \\ Jalan Soekarno-Hatta No.444, Bandung \\ *Corresponding e-mail: rizki.ramdhani@esdm.go.id
}

\begin{abstract}
Indonesia has a great potential for deep-seated coal resources. To assist and support the deep-seated coal exploration, a shallow seismic reflection method is applicable for this purpose. This study has conducted a shallow seismic reflection method in Musi Banyuasin Regency, South Sumatera Province. The Muara Enim coal target varies from 100 to 500 meters from the surface. The thickness of the coal layer varies from 2 to 10.65 meters. This study uses 48 channels with $14 \mathrm{~Hz}$ single geophone and MiniSosie as the energy source. The receiver and source interval is 15 meters. This study uses a fixed receiver and moving source configuration. From the interpreted seismic section, this study identified a deep-seated coal layer target. These layers are Mangus, Burung, Benuang, Kebon and Benakat layers. A simple interpretation is analyzed by combining the seismic amplitude characteristics and the thickness of the coal layer from the borehole data. From the interpreted seismic section, deep-seated coal layer targets have strong amplitude characteristics and are continuous from southwest to the northeast with a down-dip of around $20-30^{\circ}$. This study helps to inform the operator companies who develop the utilization of deep-seated coal (coalbed methane, underground coal gasification and underground coal mining) about the effective and proper geophysical method for imaging deep-seated coal layer.
\end{abstract}

Keywords: shallow seismic reflection, deep-seated coal, Muara Enim formation.

\section{ABSTRAK}

Indonesia memiliki potensi batubara bawah permukaan yang besar. Untuk menunjang eksplorasi batubara bawah permukaan, metode seismik refleksi dangkal dapat diaplikasikan. Survey seimik refleksi dangkal ini dilakukan di Kabupaten Musi Banyuasin, Provinsi Sumatera Selatan. Target kedalaman batubara Formasi Muara Enim bervariasi dari 100 hingga 500 meter. Ketebalan lapisan batubara bawah permukaan target bervariasi dari 2 hingga 10.65 meter. Studi ini menggunakan 48 kanal dengan geofon $14 \mathrm{~Hz}$ dan Mini-Sosie sebagai sumber energi (Sumber Getar). Jarak interval penerima (geofon) dan sumber getar adalah 15 meter. Studi ini menggunakan konfigurasi "fixed receiver and moving source". Dari data penampang seismik terinterpretasi, studi dengan jelas dapat mengidentifikasi lapisan batubara bawah permukaan target. Lapisan ini adalah lapisan Mangus, Burung, Benuang, Kebon dan Benakat. Interpretasi sederhana dilakukan dengan mengkombinasikan analisis karakter amplitudo seismik dan ketebalan lapisan batubara dari data bor. Dari penampang seismik terinterpretasi, lapisan target batubara bawah permukaan memiliki karakteristik amplitudo yang kuat dan menerus dari arah barat daya ke timur laut dengan kemiringan berkisar 20-30. Studi ini membantu menginformasikan perusahaan yang sedang mengembangkan pemanfaatan batubara bawah permukaan (gas metana batubara, gasifikasi batubara bawah permukaan dan tambang batubara bawah permukaan) dengan metode geofisika yang efektif dan tepat untuk menggambarkan batubara bawah permukaan.

Kata kunci: seismik refleksi dangkal, batubara bawah permukaan, formasi Muara Enim. 


\section{INTRODUCTION}

Geologically, Indonesia has a great potential of deep-seated coal resources. Total resources of the deep-seated coal in Indonesia are 43.02 billion tons (PPSDMBP, 2020). Deep-seated coal is a coal in a range of depth more than 100 meters below the surface. The utilization of deep-seated coal in Indonesia can be developed through the underground mining, coalbed methane (CBM), and underground coal gasification. The underground coal mining has begun its operation since 1892 in Ombilin West Sumatera (Friederich and van Leeuwen, 2017). Indonesia has begun the CBM operation in 2003 with two working areas, namely at Kutai Basin and South Sumatra Basin. Recently, The Research and Development Centre for Mineral and Coal Technology (tekMIRA) developes a pilot project of Underground Coal Gasification (UCG) in Indonesia. There are some specific requirements to utilized deep-seated coal as UCG or CBM, such as thickness, rank, ash, moisture content, depth of coal layer target, geological structure and overburden properties (Dwitama et al., 2017; Purnama and Huda, 2019). All utilizations need a technology that can estimate and delineate the depth and the thickness of the deepseated coal layer target.

Geophysical methods are generally used for imaging the subsurface. Seismic reflection is part of the geophysical method which uses an acoustic wave for imaging the subsurface. Seismic reflection is the most widely and predominant used for hydrocarbon exploration since around 1920. Since around 1980, seismic reflection has been used not only for geotechnical and environmental purposes but also for underground coal exploration at which the depths of the target are typically less than 500 meters or shallow. Presently, the application of shallow seismic reflection survey includes mapping the quarternary deposits (Okkonen and Moisio, 2015; Maraio et al., 2018), buried rock valleys and shallow faults (Li et al., 2016; Burschil et al., 2018), hydrogeology studies (Al-Shuhail and Adetunji, 2016; Miller et al., 2016), mineral exploration (Hajnal et al., 2015; Malehmir et al., 2015), geotechnical investigation and hazard mitigation (Baradello and Accaino, 2016; Dehghannejad et al., 2017).
The use of shallow seismic reflection for imaging deep-seated coal layers was rapidly developed in several countries such as America, Australia, Canada and China since around 1980. From America, geophysicist uses 2D-3D high-resolution seismic reflection for identifying deep-seated coal layer and geotechnical studies in the coalfield area. In Australia, Driml, Reveleigh and Bartlett (2001); Hearn, (2004) and Zhou et al. (2014) developed a proper acquisition, instrumentation and signal analysis for shallow seismic reflection. Nowadays, In China, (Zou et al., 2013) and (Cao, Chang and Yao, 2019) developed the advanced seismic signal analysis not only for delineating deep-seated coal layer but also predict the methane content from coal. To acquire the objective for imaging deep-seated coal, geophysicists need to calibrate the seismic data with geological data (bore-hole, outcrop, geology and laboratory data). Sometimes, to increase the quality of data interpretation, the shallow seismic reflection method is combined with other geophysical methods such as electrical resistivity tomography (ERT), groundpenetrating radar (GPR), Electromagnetic (AMT, CSAMT, TDEM) and borehole geophysics. Shallow seismic reflection may support the exploration drilling program by providing continuous subsurface seismic sections between the boreholes. In Indonesia, the research of seismic reflection surveys for coal is still limited. Generally, the use of the seismic reflection method in Indonesia is for underground planning, geotechnical and mine safety purposes (Kusumo, Sulistijo and Notosiswoyo, 2013). On the other side, geophysics study uses existing 2D or 3D conventional seismic data from oil and gas companies. CBM exploration usually requires advanced seismic analysis such as AVO and multi attributes (Wang et al., 2011; Haris, 2017).

This study explains the application of $2 \mathrm{D}$ shallow seismic for developing CBM exploration, the geology and reflection survey for imaging deep-seated coal layer from acquisition, seismic data processing and quick-simple interpretation. The location of this study is near Plakat Tinggi district, Musi Banyuasin Regency, South Sumatera Province. The depth of the coal layer target varies from 100 to 500 meters. The coal layers target is in Muara Enim Formation. The main objective of this study is delineating deep-seated coal layer and imaging 
subsurface configuration (structure) using the shallow seismic reflection method. The quicksimple geological interpretation was conducted by combining the seismic section with the existing borehole and outcrop data from the previous survey. Advancing this knowledge could help to inform the companies or operators who develop the utilization of deep-seated coal (CBM, UCG and Underground Coal Mining) about the effective and proper shallow seismic survey method for imaging deep-seated coal layer.

\section{GEOLOGICAL SETTING OF FIELD SITE}

The study site is located at Plakat Tinggi District, Musi Banyuasin Regency, South Sumatera Province (Figure 1). Geologically, this location is in South Sumatra Basin. The basin is located to the east of Barisan Mountains and extends into the offshore areas to the northeast and is regarded as a back-arc basin bounded by the Barisan Mountains to the southwest and the pre-tertiary of the Sunda Shelf to the northeast (de Coster, 1974). The youngest geological deposits are Palembang Formation which is sub-divided into three members: (1) Lower Palembang (Air Benakat Formation), Middle Palembang (Muara Enim Formation), and Upper Palembang (Kasai Formation) (Figure 2). The Air Benakat Formation was deposited during the regression that ended the deposition of Gumai Shale (Bishop, 2001). The thickness of Lower Palembang member (Air Benakat Formation) ranges from 100 to $1000 \mathrm{~m}$. In the field sites, Air Benakat formation is found in the southern part and continues from northwest to southeast in line with the Semangus river direction. Muara Enim formation was deposited as a shallow marine to continental sands, muds, and coals. This member is characterized by the presence of the coal layer (Darman and Sidi, 2000).

Coal-bearing Muara Enim Formation was deposited during Late Miocene - Early Pliocene. Boyd (1986) stated that the overall regressive Air Benakat and Muara Enim formation are interpreted as representation of deposition in a humid tropical deltaic system. Minjbouw (1978) that divided the Muara Enim formation into four parts (members), known as M1, M2, M3 and M4 (Figure 2). Based on the previous geological field mapping (Suryana, 2001), M1 member was not well developed as M2. The economically valuable coal seams are those from the M2, namely Mangus, Suban and Petai seams. Suban and Petai seams are not well developed in the field site. This member has a thickness around 50-100 meters in the field site. Muara Enim coal distribution in the field site has a belt shape distribution (anticline and syncline) and spread from the west to the east of the study area. M3 member has a widespread distribution with anticline and syncline pattern. This member has a thickness of around 150-200 meters based on the geological section. Burung and Benuang are coal layers that are well developed in this member. M4 has a thickness of around 150170 meters. This member has Kebon and Babat layers. Overlying Muara Enim formation, Kasai formation is composed of tuff, tuffaceous sand, sandstone, interbed of clay and siltstone. Suban and Semangus anticline, Pinang syncline and transform fault are the dominant structures in the field site. Suban asymmetric anticline has a northwestsoutheast direction. The northern part of this anticline has a 15-30 dipping degree. The seismic survey location is in the northern part of the Suban anticline (Figure 3).

\section{METHOD}

The basic principle of seismic reflection is an acoustic signal or seismic wave produced by an impulse source and is introduced into the ground at selected points, then this signal propagates through the subsurface and is reflected back to the surface which is detected by a receiver (Thomas, 2012). The velocity at which the signal travels depends upon the encounted rock type. When the change in velocity and density at a boundary is significant, contrast acoustic impedance and strong reflection will be generated. The difference between shallow and conventional seismic reflection is in the depth of penetration, acquisition and instrument specification, and resolution. Shallow seismic reflection generally produces signals with a higher dominant frequency than conventional seismic. This condition is required to detect a relatively thin coal layer. The coal layer target in this study varies from 2 to 10.65 meters. The shallow seismic reflection survey is successfully proved that a thin coal layer is clearly obtained in the seismic section. 


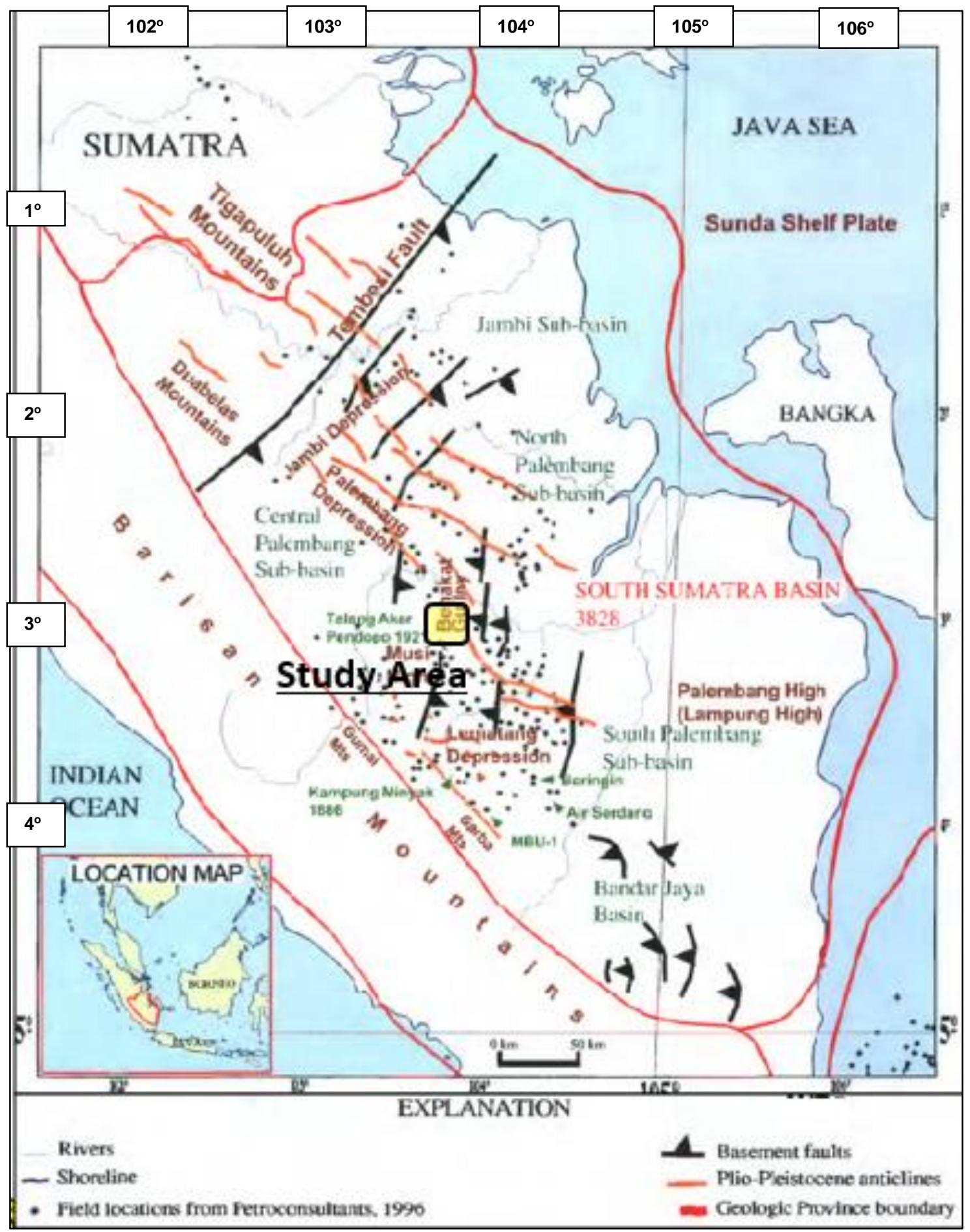

Figure 1. Field site location in South Sumatera Basin (Redrawn from Bishop, 2001) 


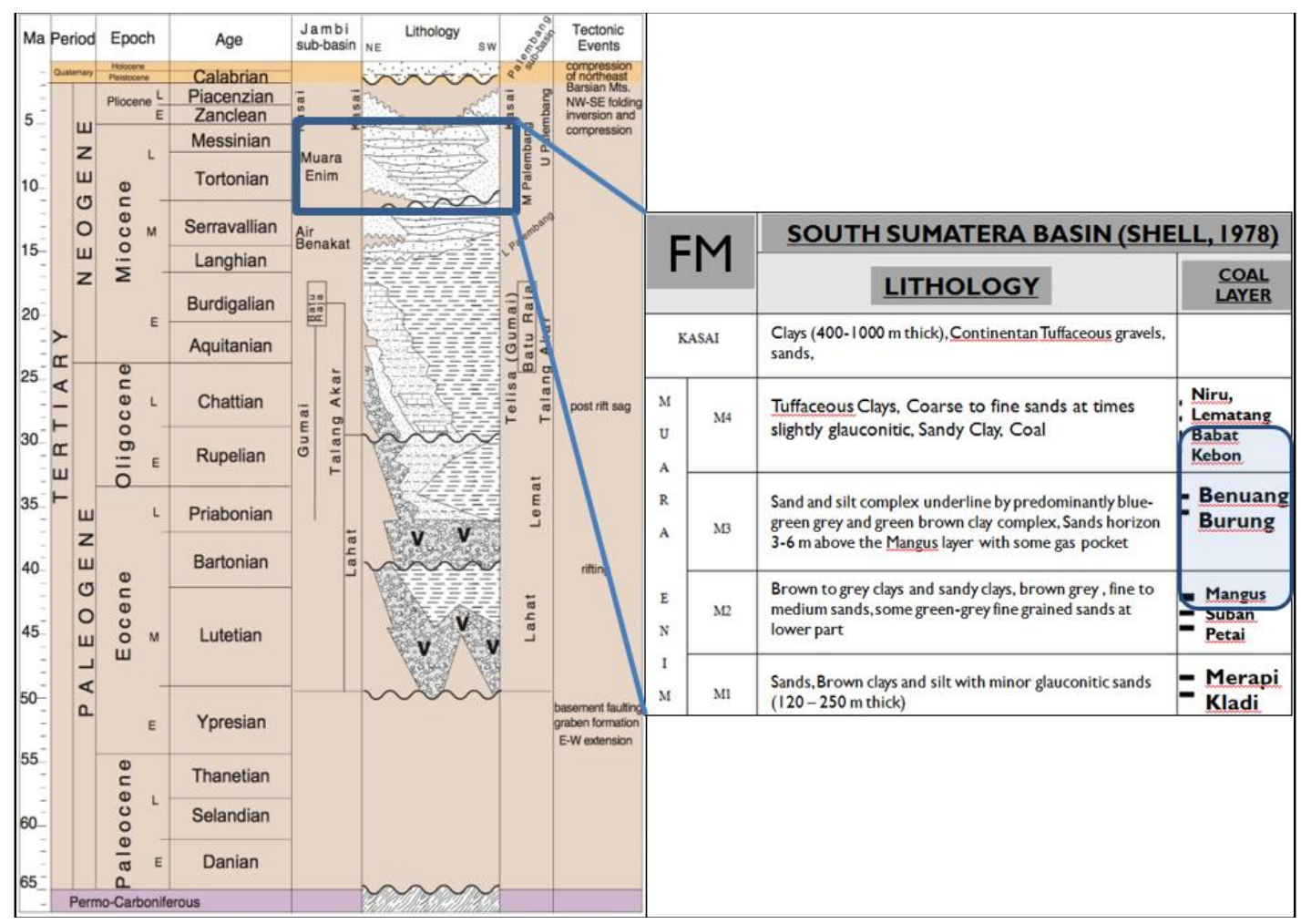

Figure 2. Stratigraphy of South Sumatra Basin and Muara Enim Sub-Formation (Modified from Bishop, 2001 and Minjbouw, 1978)

\section{The Acquisitions and Instrumentations}

Totally, two lines of shallow seismic surveys in this location have been conducted. The length of Line 1 is $4.5 \mathrm{~km}$ and Line 2 is $5 \mathrm{~km}$. The direction of these two lines is Southwest to Northeast. Its direction is perpendicular to the direction of the coal layer strike (Figure 3 ). Due to the limitation of this publication, this paper presented only one seismic line (Line1). Base on the geological map in location, the dip of the coal layer varies $5-20^{\circ}$ with the strike direction is Northwest to the Southeast. The location of the acquisition is near the rubber and palm oil plantation. The acquisition uses the "fixed receiver and moving source" configuration. A receiver (Geophone) spread is placed on the ground with the desired number of channels. The acquisition starts recording at the first end of the spread and moves along from one shot location to the next receiver spread at the desired interval while keeping the geophones fixed in place. This acquisition used multiple (Two) GEODE's 48 channels (Geometrics Instruments) with 48 single geophones (Figure 4). The geophone and source interval is $15 \mathrm{~m}$. These parameters were selected according to the requirement of the depth of the deep-seated coal layer target and the effectiveness of field operation. It is common to increase the minimum offset to avoid noise from a surface such as a ground roll. This study has recorded 334 shot gathers in this line.

This study uses Mini-Sosie as the source of the shallow seismic survey. The use of MiniSosie as the source has led to the efficiency of the shallow seismic survey in Australia (Strong, Alderman and Hearn, 2016). For shallow targets $(200-600 \mathrm{~m})$, Mini-Sosie is quite applicable and more effective in mobility than the explosive source or weight drop. The Mini-Sosie system is based on the transmission of long duration, pseudorandom impulses into the subsurface and powered by gasoline. This system is controlled by 2-4 crews (depend on the number of Mini-Sosie) in the field. The signal generated by Mini-Sosie will be evaluated by the field operation geophysicist. The record length of duration is 32 seconds with a $2 \mathrm{~ms}$ sample interval. During the acquisition, we disabled the filter process. The filter process will be analyzed in the processing sequence. 
The relatively weak signal from mini-Sosie will be progressively time-shifted and stacked to the previous raw-gather until satisfactory and clearly signal amplitudes are obtained. The raw data obtained from the acquisition system is correlated by the "random-source correlation" module from Geometrics Instruments. The pseudo-random technique is widely described by numerous geophysicists and provided the simplest wavelet (Strong and Hearn, 2004). This study uses a single geophone with a 14 $\mathrm{Hz}$ natural frequency. Generally, highresolution seismic survey needs a geophone with a higher natural frequency. Presently, it is appropriate to choose the $10-40 \mathrm{~Hz}$ geophone for the shallow target with a high-resolution seismic survey (Li, Chen and Zhong, 2009).
Hearn and Hendrick (2001) said the coal reflected waves span the bandwidth from 0 up to approximately $250-300 \mathrm{~Hz}$. Geophone with 30-40 Hz natural frequency should be more applicable to these bandwidth requirements. Unfortunately, the geophone with a $14 \mathrm{~Hz}$ natural frequency has a lower resolution than the $30-40 \mathrm{~Hz}$ geophone. This condition will provide lower bandwidth data and the limitation of coal thickness resolution. In this study, we have tested and proved, that the single geophone with a natural frequency of $14 \mathrm{~Hz}$ is quite applicable for imaging the Muara Enim coal layer. The quality of seismic data can be evaluated from shot gather, spectral analysis and seismic stacked section (Figure 6).

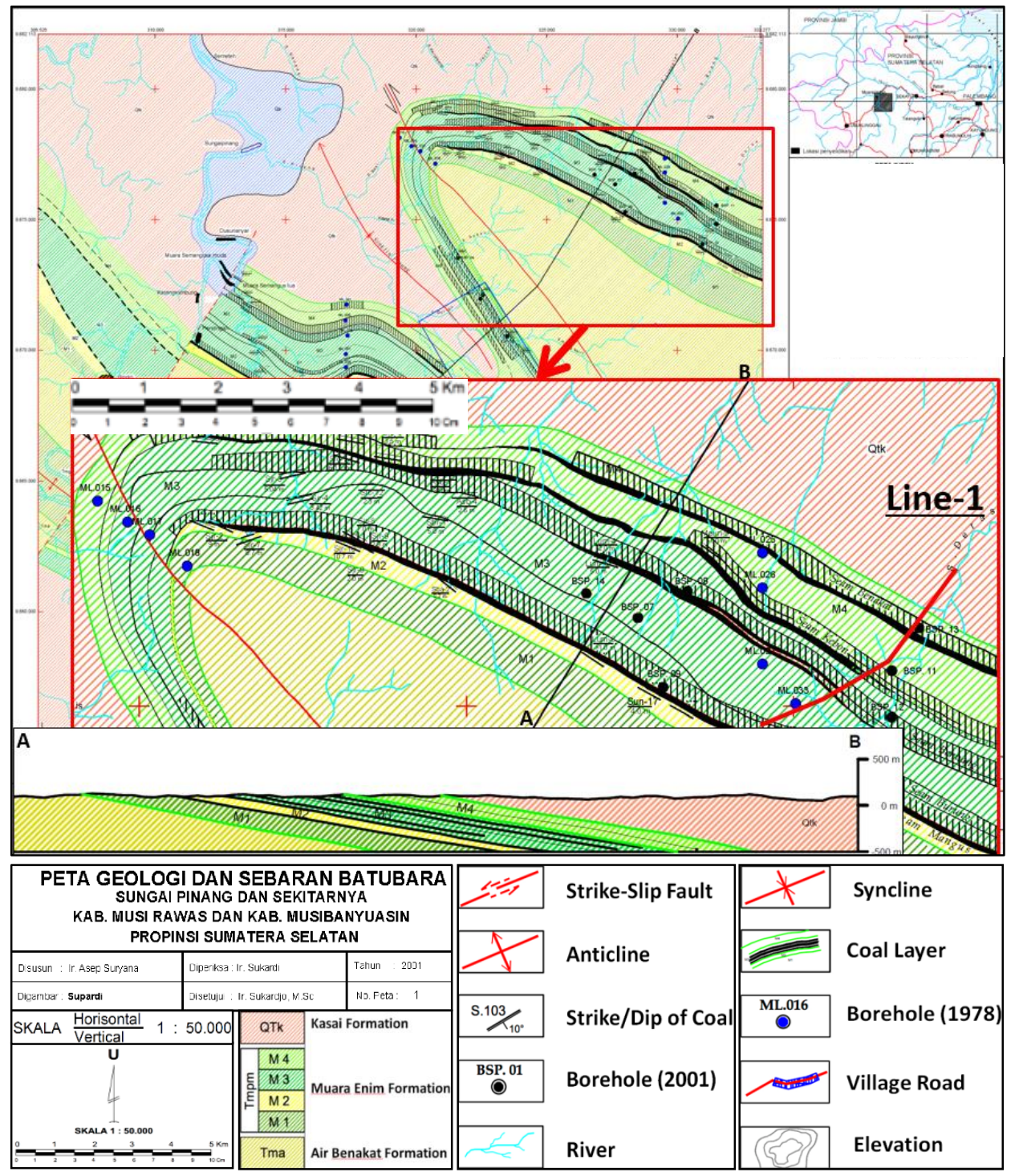

Figure 3. Geological map of the study area and coal layer distribution (Modified from Suryana, 2001) 


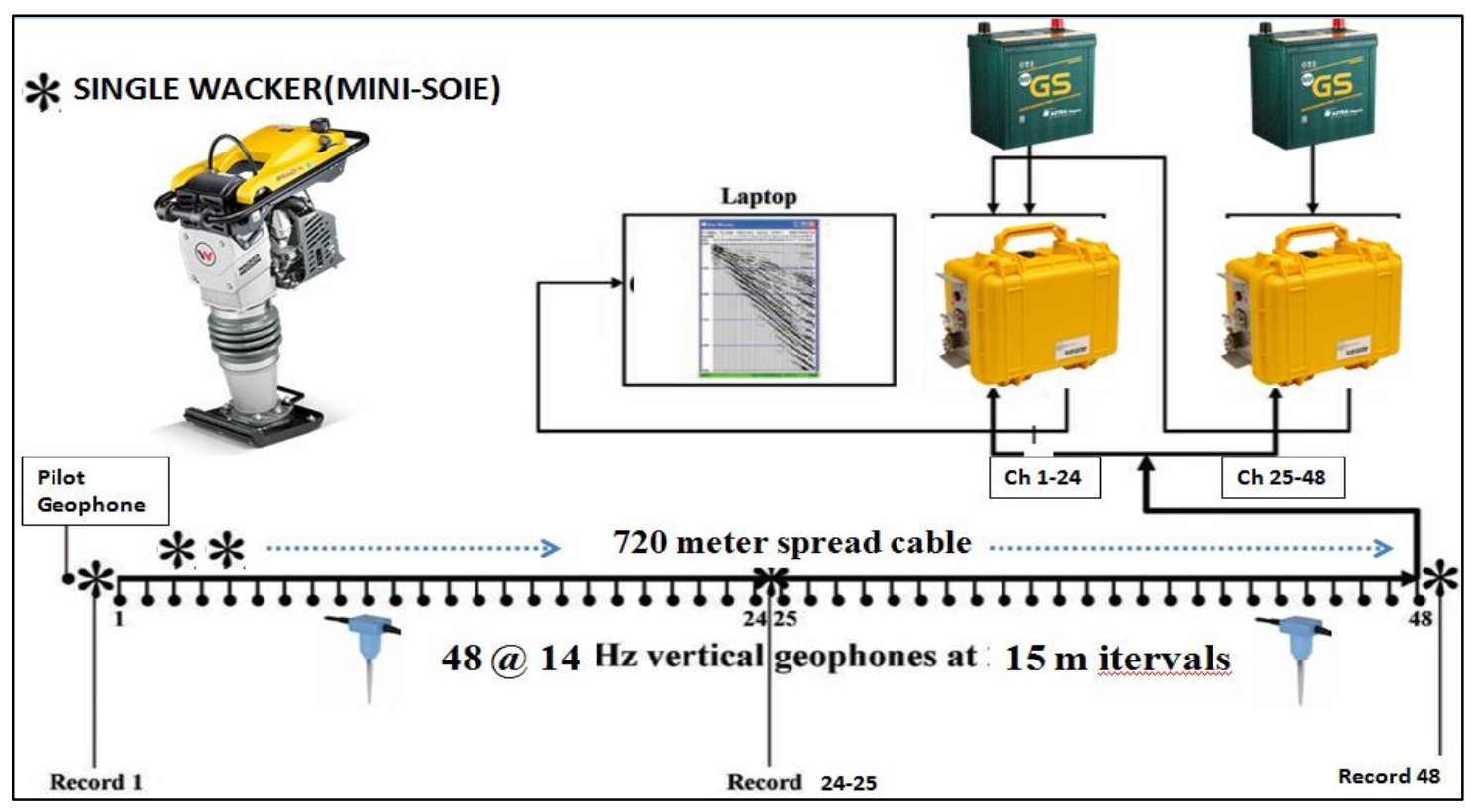

Figure 4. Seismic acquisition and instruments

\section{Data Processing}

The simple processing scheme was applied to provide a high $\mathrm{S} / \mathrm{N}$ seismic section. The processing sequence shown in Figure 5 was designed based on raw data conditions and high $\mathrm{S} / \mathrm{N}$ requirements. This processing scheme was to preserve amplitude and maintain high-frequency seismic data. There are three basic stages in processing seismic data: deconvolution, stacking and migration (Bracewell et al., 2001). In addition, there are some auxiliary and modifications in parameters of basic processing seismic scheme related to shallow seismic data processing requirements. For example, Yilmaz (2015) said shallow land seismic doesn't need or desire for the deconvolution process because it will interfere with the presence of velocity variations associated with complex subsurface conditions. These modifications are required to improve the signal to the ratio of the data and vertical resolution. The simple seismic processing is divided into two main sequences, preprocessing and processing (Figure 5).

\section{Pre-processing}

In this sequence, seismic raw data (shotgather) will be inputted into the seismic processing software. The shot-gather format is in SEG-Y format from seismic acquisition software. Geometry data such as coordinates, elevation, number of channels, number of live receivers and source, fold and pattern from the acquisition logbook are important for processing seismic data. After input SEG-Y and geometry data, the next sub-pre-processing sequences are editing and muting. In these sequences, bad traces from the acquisition are selected to be removed. Trace muting was applied to remove refracted, direct and airwave. The next step is bandpass filtering. This filter applies frequency filters for each seismic trace data. In this filtering, we choose 20-25 $\mathrm{Hz}$ as a low cut filter and $200-250$ as a high cut filter. In some cases, a lower cut filter of $8-10 \mathrm{~Hz}$ will be applied to remove the ground roll with lower frequency content. These parameters were chosen to maintain the dominant frequency data and remove the low frequency (ground roll) and high-frequency noise. (Li, Peng and Zou, 2015) the combined cross spread cone filter with surface constant deconvolution to improve the seismic resolution of the coal layer. All of these studies are current developments in seismic processing techniques and have not been applied by this study. 


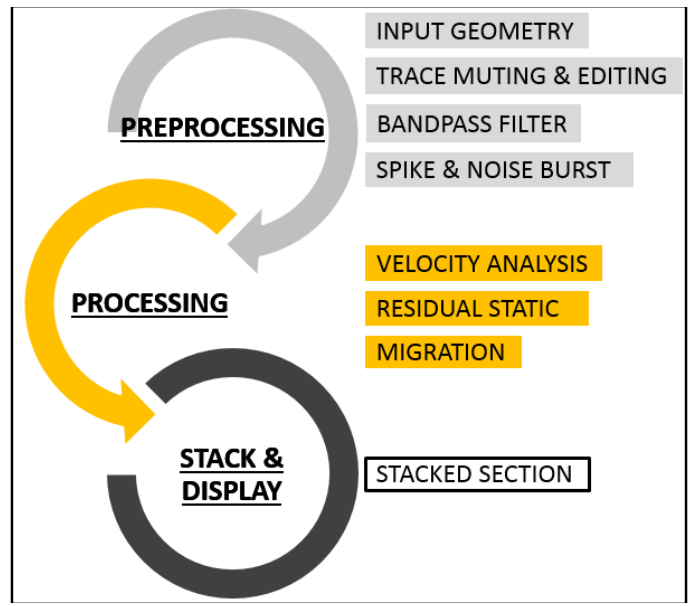

Figure 5. Seismic data processing flowchart

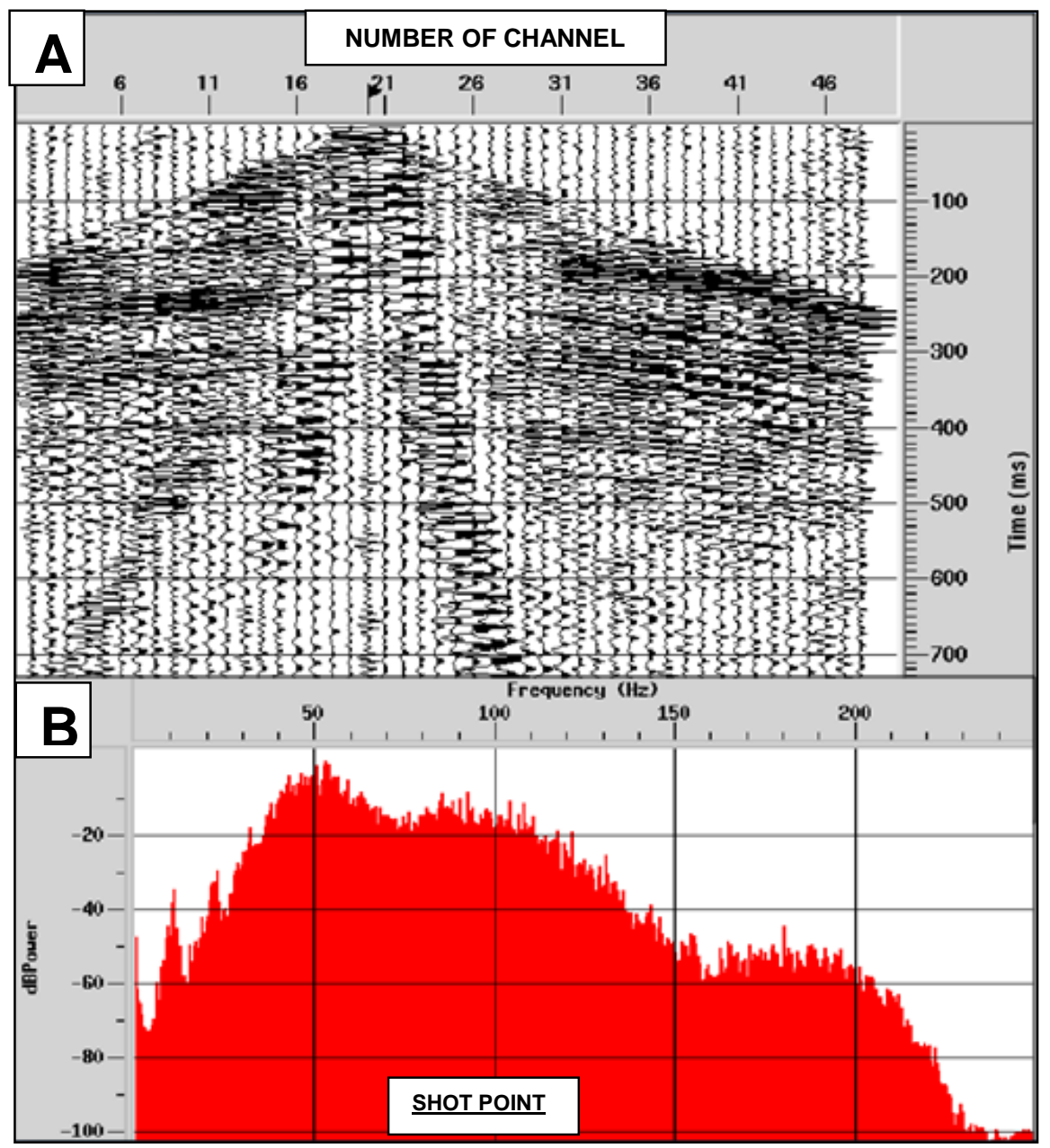

Figure 6. Shot gather (raw data) (A) and its spectrum (B).

Deconvolution was applied to remove the basic seismic wavelet by compressing the shape of the wavelet and attenuating reverberations (Backus et al., 2001).
Deconvolution is commonly applied before stack; however, it is common to use after stack. In this study, the $f-x$ deconvolution to the stacked seismic data is applied. F-X 
deconvolution uses $\mathrm{f}$ - $\mathrm{x}$ prediction filtering for random noise reduction. The additional in this sequence is spike and noise burst analysis. Spikes and bursts are usually caused by instrument noise (cable, electricity and instruments), footsteps and raindrops. Spike and noise burst detect and edit single sample spikes and multiple sample bursts of noise. The product of this sequence will be stacked and displayed in the seismic section (Figure 7).

\section{Processing}

In this sequence, seismic trace data will be analyzed in velocity analysis. Velocity analysis provides comprehensive interactive velocity analysis, velocity quality control and velocity field modification capabilities. Typically, this process involves comparing a series of stacked traces in which a range of velocities will be obtained and applied for Normal Moveout (NMO) correction. This process usually displays on the velocity semblance spectrum.

The next step is Residual Static. Even though elevation static corrections have been applied to remove travel-time effects of elevation changes along the seismic line, it may still be necessary to remove residual near-surface travel time delays that are the result of varying velocity and/or varying depth of the weathering layer. This process used 2D/3D Maximum Auto-statics Horizon which was developed by Ronen and Claerbout (1985). This concept considers determining the residual static at a shot station. Velocity analysis and residual statics were applied twice in this sequence. This repetition was applied due to different effects on the velocity after residual static. Finally, the Post Stack Kirchoff Time Migration process will be applied in the processing sequence. Migration moves dipping reflections to their true subsurface positions and collapses diffractions, thus increasing spatial resolution and yielding a seismic image of the subsurface (Baysal et al., 2001). This common migration processing was based on two general assumptions, (1) subsurface reflectors are horizontally layered media and (2) common midpoint (CMP) stack is equivalent to the zero-offset section (Yilmaz and Claerbout, 1980). Presently, some development in post-stack and pre-stack migration has been successful to improve the quality of seismic data for coal (Yuan et al., 2011).

\section{Borehole Data}

There are four boreholes near the seismic line-1, ML-33, BSP-12, BSP-11 and BSP-13 (Table 1). These boreholes have a total depth of around 50 meters (BSP-11, 12 and 13) and 120 meters (ML-33) from the surface. From ML-33, the thickness of the Mangus layer is around 10.65 meters. From BSP-12, the thickness of the Benuang layer is around 1.75 meters. From BSP-11, the thickness of the Kebon layer is around 2 meters. From BSP13 , the Benakat layer has a thickness of around 8.5 meters. The geophysical data log is not available on these boreholes. Located around 2-3 km northwest from line-1, BSP-14 presents the Burung layer with a thickness of around $2 \mathrm{~m}$. All of the layers (Mangus, Burung, Benuang, Kebon and Benakat) are continuous from southeast to northwest of the area study.

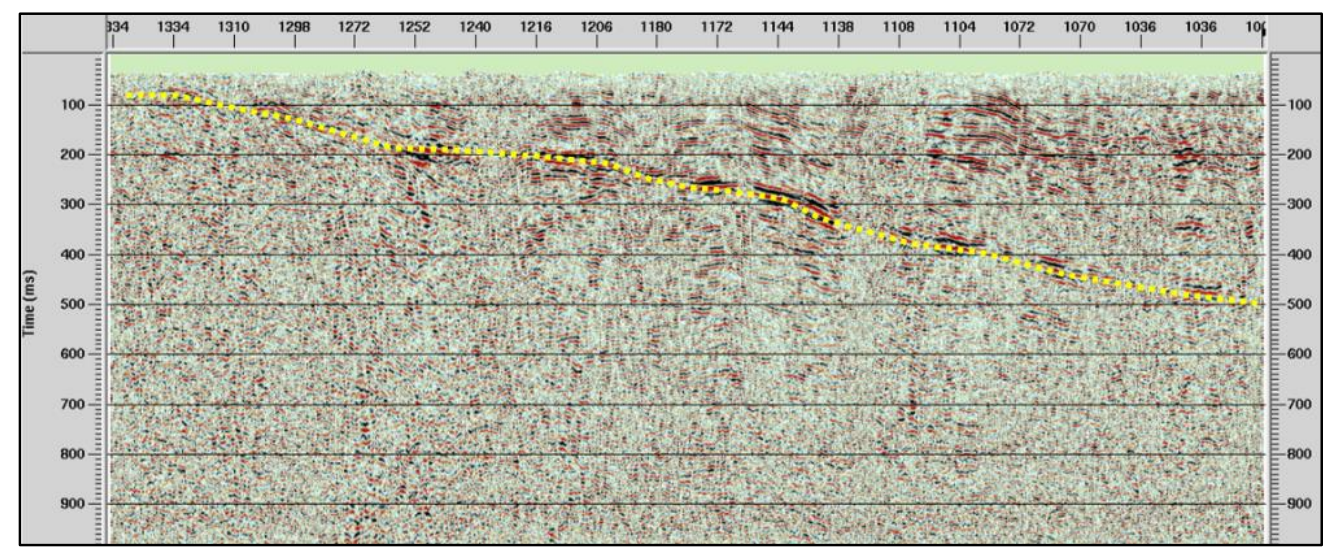

Figure 7. Seismic Line-1 Pre-Processing Stacked Section (Brute Stack). 
Table 1. Borehole data

\begin{tabular}{cccc}
\hline Borehole Name & Coal Layer & Thickness $(\mathrm{m})$ & Depth $(\mathrm{m})$ \\
\hline ML-33 & Mangus Layer & 10.65 & $55-65.65$ \\
BSP-12 & Benuang Layer & 3.5 & $2.75-4.5$ and 34.75 - 36.5 \\
BSP-11 & Kebon Layer & 2 & $27-29$ \\
BSP-13 & Benakat Layer & 8.5 & $16-24.5$ \\
\hline
\end{tabular}

\section{RESULTS AND DISCUSSION}

\section{Seismic Data Analysis}

To evaluate the quality of seismic data, this study reviews the data quality from shot gather (a seismic raw record), dominant frequency (spectral analysis) and seismic stacked section. From good quality shots gather (Figure 6), the seismic events such as direct wave, reflection, and noise (ground roll and other high-frequency noise) can be clearly identified. From bad records gather, the reflection event is vague to identify because of noise from the instrument and traffic. Traffic noises are frequently recorded since the acquisition location enters the crowd in the village. Ground roll and highfrequency noise are clearly removed from seismic data by trace edit, bandpass filter, spike \& noise burst in pre-processing sequence. From the spectral analysis, the dominant frequency of seismic data is $50 \mathrm{~Hz}$. Dominant frequency presents the frequency of the seismic reflection data. From seismic velocity semblance, the velocity is picked between 1000-2500 m/s. The velocity increase with increasing depth. This natural condition is the effect of the compacted and cemented sediments when they are buried deeper in the subsurface (Veeken and Moerkerken, 2013).

The seismic stacked section displayed subsurface configuration with various dipping layers from northwest to southeast. The strong reflection can be identified in the preprocessing sequence (Figure 7). This reflection is continuous from the northwest with an approximate dip of 20 degrees to the southeast (yellow dash). The deepest reflection can be identified up to $500 \mathrm{~ms}$. After velocity analysis, residual static, and migration, the strong reflection is clearer and more continuous than before. From seismic shot gather, spectral analysis and seismic stacked section, this study has successfully proved that the specification of the instrument (geophone $14 \mathrm{~Hz}$ ) and acquisition parameters are suitable for imaging deepseated layer targets in this location.

\section{Seismic Response of Coal Layer}

To identify the seismic response of the coal layer, this study will refer to the physical properties of coal and the vertical resolution of seismic data from many kinds of literature. Physical properties such as density and velocity are the basic parameters to determine and study the contrast acoustic impedance between coal and surrounding rocks. Generally, coal has low velocity and low density which generates low acoustic impedance. The study of these physical (acoustic/elastic) properties of coal are generally described by many geophysicists with their laboratory experiments (Yao and Han, 2008; Morcote, Mavko and Prasad, 2010; Dirgantara, Batzle and Curtis, 2011; Pan et al., 2013; Li, Chen and He, 2016; Zou et al., 2018). In Indonesia, Yushendri et al. (2013) investigate the relationships between coal rank and pressure with dynamic elastic properties of Muara Enim coal. Generally, the result of these experiments shows that the elastic/acoustic properties of different coal ranks depend on confining pressure. All of these laboratory experiments have not been explicitly and directly confirmed by this study.

To determine the velocity of the predicted coal layer, we obtained the velocity from velocity analysis in processing sequences. In contrast to low acoustic impedance to the surrounding rocks, coal has a bright amplitude (strong reflection) response on seismic data. Its characteristic can be seen in the seismic stacked section (Figure $7 \& 8$ ). Furthermore, Peng, Wei and Di (2015) with their physical model simulation have shown seismic energy is strongly attenuated as seismic wave penetrates the coal layer and makes underlying layers cannot be clearly imaged. Besides the shielding effect, the existence of the coal layer can confuse the seismic interpreter in oil \& gas companies because it tends to generate the same 
anomaly as the gas sand (bright spot) (Chopra and Castagna, 2014; Simm and Bacon, 2014). The thickness of coal layer data is required to specify the resolution requirement of seismic data. Vertical resolution is a common issue for this survey since shallow seismic surveys provide higher frequency data. The vertical resolution for conventional seismic is $\lambda / 4$ ( $\lambda$ is wavelength) (Widess, 1973). Coal layers are thin due to the seismic wavelength and have contrast impedance with surrounding rocks. Because of the thickness and contrast impedance, the limit of detection of coal seams is less than other strata and may be as small as $\lambda / 40$ (Gochioco, 1992). From the spectral analysis, the dominant frequency of our seismic data is around $50 \mathrm{~Hz}$. The velocity value obtained from seismic processing is around $2000 \mathrm{~m} / \mathrm{s}$. The velocity of coal from many kinds of literature are around 1800-2500 m/s (Mavko, Mukerji and Dvorkin, no date; Thomas, 2012). Based on the velocity and dominant frequency of this study, the one-quarter of wavelength $(\lambda / 4)$ of our seismic data is around 10 meters. Coal thickness varies from $3-12$ meters in the seismic study location. The coal layer with a thickness of more than 10 meters will be distinct and separate in amplitude reflection. The coal layer thickness of less than 10 meters will not be separated from a coal layer with a thickness of more than 10 meters.

\section{Geology Interpretation}

As the limitation of the data (well log) in this study, the interpretation of the deep-seated coal layer was based on the thickness of the coal layer (bore-hole data) and amplitude characteristic from the seismic section. Before the interpretation, the seismic section in the time domain will be converted to a depth section by simple calculation with the velocity model from velocity analysis. After the borehole and seismic sections are in the same domain (depth), the interpretation will predict the horizon target (coal layer) from borehole data and delineate the predicted coal layer by picking the continuous bright amplitude from the seismic section.
From the seismic section, the characteristics of seismic reflection such as continuity and amplitude can be clearly identified. The reflection continuity describes information about the continuity of the layer and is directly related to the sedimentary process and environment of deposition. The reflection amplitude provides the information one reflection strength, the contrast of lithology, and fluid contents (Veeken and Moerkerken, 2013). The bright amplitude (strong reflection) is clearly identified in the seismic section. The brightest amplitude is continuous from the southwest at depth of 70 80 meters to the northeast at a depth up to 500 meters (Figure 8). This characteristic can be interpreted as the Mangus layer. The strong Mangus reflection is continuous from southwest to northeast with an approximate dip of $20^{\circ}$. The Mangus thickness from borehole data (ML-33) is 10,5 meters and matches the bright amplitude from the seismic section. Above the Mangus layer, Burung, Benuang, Kebon and Benakat layers have the same configuration as the Mangus layer. The amplitude reflection characteristic of these layers is weaker than the Mangus layer. This amplitude characteristic is correlated with the thickness of the layer. Mangus has the thickest layer from the other layer. According to the borehole BSP-12, the Benuang layer has a thickness of around 3,5 meters and is continuous with down-dip 20 to the northeast until around 300 meters of depth. Located is in the middle of the line, the Kebon layer started from a depth of 27 meters (BSP-11) continuous with the same dip of the Mangus layer to the northeast and end up at approximately 250 meters of depth (from the seismic section). The Kebon layer has a thickness of around 2 meters. Above the Kebon layer, the Benakat layer is continuous to the northeast up to 120 meters of depth with the same configuration as the Mangus layer (from seismic section). The configuration of the subsurface layer from the seismic section is matched with the geological section from the previous survey (Suryana, 2001). The northern part of Suban anticline and the dipping of the coal layer were clearly imaged in the seismic section. 


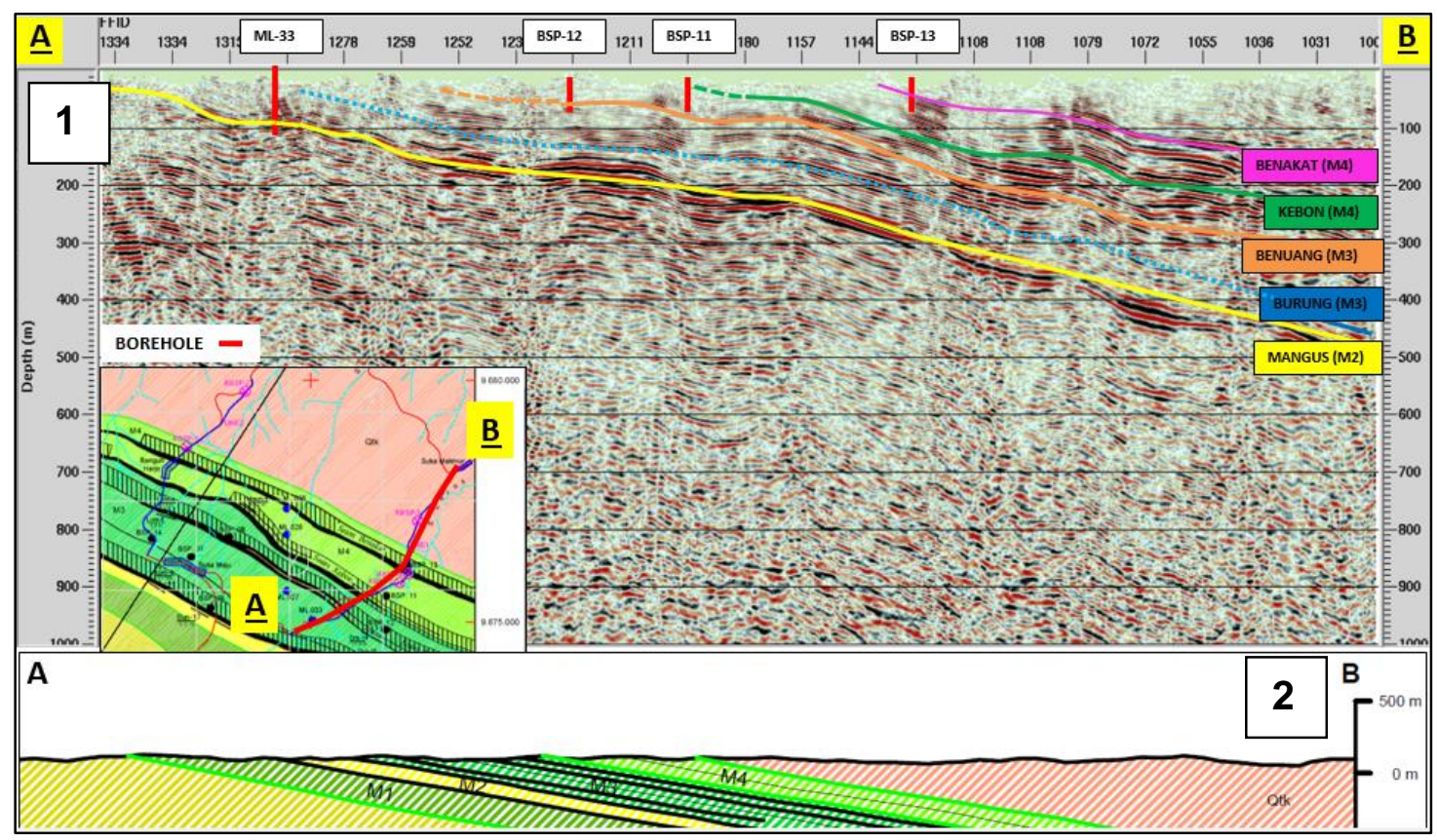

Figure 8. Seismic Line-1 Interpreted Section (1) and Geological Section (2)

\section{CONCLUSION AND SUGGESTION}

This study demonstrates the application of shallow seismic reflection method for imaging deep-seated coal layers. The studies presented in this paper have a cognitive and practical aspect. Shallow seismic reflection is very applicable for imaging deep-seated layers. From the seismic section and borehole data, the subsurface configuration can be clearly identified and delineate the deep-seated coal layers. The northern part of Suban anticline is clearly imaged in the seismic section. Deep-seated coal layers (Mangus, Burung, Benuang, Kebon and Benakat) have strong amplitude characteristics and are continuous with the down dip around $20-30^{\circ}$ based on seismic section. The thickness of coal varies from 2 to 12 meters based on borehole and outcrop data. Mangus layer has the brightest amplitude characteristic among all of the coal layers in the seismic section. This study may support and be applicable for CBM, UCG and Underground coal exploration.

\section{ACKNOWLEDGEMENT}

The authors would like to thank the Center for Mineral Coal and Geothermal resources, Geological Agency, Ministry of Energy and
Mineral Resources for their support to publish this paper.

\section{REFERENCES}

Al-Shuhail, A. A. and Adetunji, A. (2016) 'Joint inversion of ground-penetrating radar and seismic velocities for porosity and water saturation in shallow sediments', Journal of Environmental and Engineering Geophysics, 21(3), pp. 105119. doi: 10.2113/JEEG21.3.105.

Backus, M. M. et al. (2001) 'Deconvolution', in Doherty, S. M. (ed.) Seismic Data Analysis. Society of Exploration Geophysicists, pp. 159-270. doi: 10.1190/1.9781560801580.ch2.

Baradello, L. and Accaino, F. (2016) 'GPR and high resolution seismic integrated methods to understand the liquefaction phenomena in the Mirabello Village (earthquake ML 5.9, 2012)', Engineering Geology, 211, pp. 1-6. doi: 10.1016/j.enggeo.2016.06.027.

Baysal, E. et al. (2001) 'Migration', in Doherty, Stephen M. (ed.) Seismic Data Analysis. Society of Exploration Geophysicists, pp. 463-654. doi: $10.1190 / 1.9781560801580 . c h 4$.

Bishop, M. G. (2001) South Sumatra Basin Province, Indonesia; the Lahat/Talang 
Akar-Cenozoic total petroleum system. Reston, Virginia.

Boyd, J. D. (1986) 'Sedimentological analysis of a Miocene deltaic systems: Air Benakat and Muara Enim Formations, Central Merangin Block, South Sumatra', in Proc. Indon Petrol. Assoc., 15th Ann. Conv. Jakarta: Indonesian Petroleum Association (IPA), pp. 245-258. doi: 10.29118/IPA.1265.245.258.

Bracewell, R. N. et al. (2001) 'Fundamentals of signal processing', in Doherty, S. M. (ed.) Seismic Data Analysis. Society of Exploration Geophysicists, pp. 25-158. doi: 10.1190/1.9781560801580.ch1.

Burschil, T., Buness, H., Tanner, D. C., WielandtSchuster, U., Ellwanger, D. and Gabriel, G. (2018) 'High-resolution reflection seismics reveal the structure and the evolution of the Quaternary glacial Tannwald Basin', Near Surface Geophysics, 16(6), pp. 593-610. doi: $10.1002 /$ nsg.12011.

Cao, L., Chang, S. and Yao, Y. (2019) 'Application of seismic sedimentology in predicating sedimentary microfacies and coalbed methane gas content', Journal of Natural Gas Science and Engineering, 69, p. 102944.

doi: 10.1016/j.jngse.2019.102944.

Chopra, S. and Castagna, J. P. (2014) 'Seismic observations and historical developments leading to AVO', in AVO. Society of Exploration Geophysicists, pp. 35-57. doi: 10.1190/1.9781560803201.ch3.

De Coster, G. L. (1974) 'The geology of the Central and South Sumatra Basins', in Proc. Indon Petrol. Assoc., 3rd Ann. Conv. Jakarta: Indonesian Petroleum Association (IPA), pp. 77-110. doi: 10.29118/IPA.670.77.110.

Darman, H. and Sidi, F. H. (eds) (2000) An outline of the geology of Indonesia. Jakarta: Indonesian Association of Geologists.

Dehghannejad, M., Malehmir, A., Svensson, M., Lindén, M. and Möller, H. (2017) 'Highresolution reflection seismic imaging for the planning of a double-train-track tunnel in the city of Varberg, southwest Sweden', Near Surface Geophysics, 15(3), pp. 226-240. doi: 10.3997/18730604.2017011

Dirgantara, F., Batzle, M. L. and Curtis, J. B. (2011) 'Maturity characterization and ultrasonic velocities of coals', Society of
Exploration Geophysicists International Exposition and 81st Annual Meeting 2011, SEG 2011, pp. 2308-2312.

Driml, K., Reveleigh, M. and Bartlett, K. (2001) 'Mini-SOSIE - Successful shallow 3D seismic data acquisition in an environmentally sensitive area', ASEG Extended Abstracts, 2001(1), pp. 1-4. doi: 10.1071/ASEG2001ab033.

Dwitama, E. P., Ramdhani, M. R., Firmansyah, F. and Purnomo, W. S. (2017) 'Evaluasi potensi batubara untuk underground coal gasification pada lubang bor JWT-02, Daerah Ampah, Kabupaten Barito Timur, Provinsi Kalimantan Tengah', Buletin Sumber Daya Geologi, 12(3), pp. 184192. doi: $10.47599 /$ bsdg.v12i3.50.

Friederich, M. C. and van Leeuwen, T. (2017) 'A review of the history of coal exploration, discovery and production in Indonesia: The interplay of legal framework, coal geology and exploration strategy', International Journal of Coal Geology, 178 , pp. 56-73. doi: 10.1016/j.coal.2017.04.007

Gochioco, L. M. (1992) 'Modeling studies of interference reflections in thin-layered media bounded by coal seams', GEOPHYSICS, 57(9), pp. 1209-1216. doi: 10.1190/1.1443336.

Hajnal, Z., Takacs, E., Pandit, B. and Annesley, I. R. (2015) 'Uranium mineralization indicators from seismic and well log data in the Shea Creek area at the southern margin of the Carswell impact structure, Athabasca Basin, Canada', Geophysical Prospecting, 63(4), pp. 861-880. doi: $10.1111 / 1365-2478.12274$.

Haris, A. (2017) 'Coal bed methane properties modeling using improved seismic resolution for estimating gas reserves: $A$ case study of East Kalimantan field, Indonesia', International Journal of GEOMATE, 13(40), pp. 81-87. doi: $10.21660 / 2017.40 .61057$.

Hearn, S. (2004) 'Shallow, high-resolution converted-wave seismology for coal exploration', ASEG Extended Abstracts, 2004(1), pp. 1-4. doi: 10.1071/ASEG2004ab066.

Hearn, S. and Hendrick, N. (2001) 'Bandwidth requirements for shallow, high-resolution seismic reflection', ASEG Extended Abstracts, 2001(1), pp. 1-4. doi: 10.1071/ASEG2001ab057. 
Kusumo, A. D., Sulistijo, B. and Notosiswoyo, S. (2013) 'The conceptual method of crosswell seismic reflection for underground coal mine planning in Indonesia', Procedia Earth and Planetary Science, 6, pp. 195-201. doi: 10.1016/j.proeps.2013.01.026.

Li, D., Liao, H., Ding, Z. and Wu, P. (2016) 'Detection of the Shuangshi-Dachuan fault using shallow seismic reflection in the Southern Section of the Longmenshan fault zone', Journal of Environmental and Engineering Geophysics, 21(4), pp. 161-172. doi: 10.2113/JEEG21.4.161.

Li, G., Chen, G. and Zhong, J. (2009) 'Analysis of geophone properties effects for land seismic data', Applied Geophysics, 6(1), pp. 93-101. doi: 10.1007/s11770-0090003-4.

Li, Q., Chen, J. and He, J. (2016) 'Experimental study of rock physics of coalbed methane reservoirs in Qinshui Basin', in 2016 Workshop: Rock Physics and Borehole Geophysics, Beijing, China, 28-30 August 2016. Society of Exploration Geophysicists, pp. 13-16. doi: 10.1190/RP2016-004

Li, Q., Peng, S. and Zou, G. (2015) 'High resolution processing of 3D seismic data for thin coal seam in Guqiao coal mine', Journal of Applied Geophysics, 115, pp. 32-39. doi: 10.1016/j.jappgeo.2015.02.014.

Malehmir, A., Wang, S., Lamminen, J., Brodic, B. Bastani, M., Vaittinen, K., Juhlin, C. and Place, J. (2015) 'Delineating structures controlling sandstone-hosted base-metal deposits using high-resolution multicomponent seismic and radiomagnetotelluric methods: a case study from Northern Sweden', Geophysical Prospecting, 63(4), pp. 774-797. doi: 10.1111/1365-2478.12238.

Maraio, S., Bruno, P. P. G., Picotti, V., Mair, V. and Brardinoni, F. (2018) 'High-resolution seismic imaging of debris-flow fans, alluvial valley fills and hosting bedrock geometry in Vinschgau/Val Venosta, Eastern Italian Alps', Journal of Applied Geophysics, 157, pp. 61-72. doi: 10.1016/j.jappgeo.2018.07.001.

Mavko, G., Mukerji, T. and Dvorkin, J. (no date) 'Empirical relations', in The Rock Physics Handbook. Cambridge: Cambridge University Press, pp. 347-388. doi: 10.1017/CBO9780511626753.008.
Miller, R., Black, W., Miele, M., Morgan, T., Ivanov, J., Peterie, S. and Wang, Y. (2016) 'Highresolution seismic reflection to improve accuracy of hydrogeologic models in Ventura County, California, USA', The Leading Edge, 35(9), pp. 760-769. doi: $10.1190 /$ tle35090760.1.

Minjbouw, S. N. V. (1978) Explanatory notes to the geological map of the South Sumatran coal Province.

Morcote, A., Mavko, G. and Prasad, M. (2010) 'Dynamic elastic properties of coal', GEOPHYSICS, 75(6), pp. E227-E234. doi: 10.1190/1.3508874.

Okkonen, J. and Moisio, K. (2015) 'Seismic reflection surveys in glaciofluvial deposits in Finland', Near Surface Geophysics, 13(5), pp. 417-433. doi: 10.3997/18730604.2015034

Pan, J., Meng, Z., Hou, Q., Ju, Y. and Cao, Y. (2013) 'Coal strength and Young's modulus related to coal rank, compressional velocity and maceral composition', Journal of Structural Geology, 54, pp. 129-135. doi: 10.1016/j.jsg.2013.07.008.

Peng, H., Wei, J. and Di, B. (2015) 'A physical model of the shielding effect of coalbeds', in SEG Technical Program Expanded Abstracts 2015. Society of Exploration Geophysicists, pp. 3651-3655. doi: 10.1190/segam2015-5863057.1.

PPSDMBP (2020) Neraca sumber daya dan cadangan mineral batubara dan panas bumi status 2019. Pusat Sumber Daya Mineral batubara dan Panas Bumi.

Purnama, A. and Huda, M. (2019) 'A preliminary study of Indonesian coal basins for underground coal gasification development', Indonesian Mining Journal, 22(1), pp. 61-76. doi: 10.30556/imj.Vol22.No1.2019.275.

Ronen, J. and Claerbout, J. F. (1985) 'Surfaceconsistent residual statics estimation by stack-power maximization', GEOPHYSICS, 50(12), pp. 2759-2767. doi: $10.1190 / 1.1441896$.

Simm, R. and Bacon, M. (2014) 'Rock properties and AVO', in Seismic Amplitude. Cambridge: Cambridge University Press, pp. 58-109. doi: $10.1017 /$ CBO9780511984501.006.

Strong, S., Alderman, J. and Hearn, S. (2016) 'Imaging of shallow coal structures using 
2D6C Mini-SOSIE', ASEG Extended Abstracts, 2016(1), pp. 1-5.

doi: 10.1071/ASEG2016ab286.

Strong, S. and Hearn, S. (2004) 'Numerical modelling of pseudo-random land seismic sources', ASEG Extended Abstracts, 2004(1), pp. 1-4.

doi: 10.1071/ASEG2004ab142.

Suryana, A. (2001) Pengkajian batubara bersistem dalam cekungan Sumatera Selatan di daerah Sungai Pinang dan sekitarnya, Kabupaten Musirawas dan Kabupaten Musi Banyuasin, Provinsi Sumatera Selatan.

Thomas, L. (2012) 'Geophysics of coal', in Coal Geology. 2nd edn. Chichester, UK: John Wiley \& Sons, Ltd, pp. 211-252. doi: 10.1002/9781118385685.ch8.

Veeken, P. C. H. and Moerkerken, B. van (2013) 'The seismic reflection method and its constraints', in Seismic Stratigraphy and Depositional Facies Models. Elsevier, pp. 15-104. doi: 10.1016/B978-0-12411455-5.50002-4

Wang, Y., Cui, R., Zhang, S., Dai, F. and Jia, W. (2011) 'Application of AVO Inversion to the Forecast of Coalbed Methane Area', Procedia Earth and Planetary Science, 3 , pp. 210-216.

doi: 10.1016/j.proeps.2011.09.085.

Widess, M. B. (1973) 'How thin is a bed?', GEOPHYSICS, 38(6), pp. 1176-1180. doi: 10.1190/1.1440403.

Yao, Q. and Han, D. (2008) 'Acoustic properties of coal from lab measurement', in SEG Technical Program Expanded Abstracts 2008. Society of Exploration Geophysicists, pp. 1815-1819. doi: 10.1190/1.3059254

Yilmaz, Ö. (2015) 'Seismic modeling of the soil column', in Miller, R. D. (ed.) Engineering
Seismology with Applications to Geotechnical Engineering. Society of Exploration Geophysicists, pp. 159-370. doi: 10.1190/1.9781560803300.ch2.

Yilmaz, Ö. and Claerbout, J. F. (1980) 'Prestack partial migration', GEOPHYSICS, 45(12), pp. 1753-1779. doi: 10.1190/1.1441064.

Yuan, Y., Gao, Y., Bai, L. and Liu, Z. (2011) 'Prestack Kirchhoff time migration of 3D coal seismic data from mining zones', Geophysical Prospecting, 59(3), pp. 455-463. doi: 10.1111/j.13652478.2010.00932.x.

Yushendri, Y. F., Sukotjo, A., Raguwanti, R., Widarto, D. S. and Nurhandoko, B. E. B. (2013) 'Seismic rock physics of the South Sumatra basin coal, Indonesia', in Proceedings of the 11th SEGJ International Symposium, Yokohama, Japan, 18-21 November 2013. Society of Exploration Geophysicists of Japan, pp. 402-406. doi: 10.1190/segj112013-102.

Zhou, B., Hatherly, P., Peters, T. and Sun, W. (2014) 'Coal seismic surveying over nearsurface basalts: Experience from Central Queensland, Australia', GEOPHYSICS, 79(2), pp. B109-B122. doi: 10.1190/geo2013-0259.1.

Zou, G., Peng, S., Yin, C., Xu, Y., Chen, F. and Liu, J. (2013) 'Seismic studies of coal bed methane content in the west coal mining area of Qinshui Basin', International Journal of Mining Science and Technology, 23(6), pp. 795-803. doi: 10.1016/j.ijmst.2013.10.003.

Zou, G., Xu, Z., Peng, S. and Fan, F. (2018) 'Analysis of coal seam thickness and seismic wave amplitude: A wedge model', Journal of Applied Geophysics, 148, pp. 245-255. doi: 10.1016/j.jappgeo.2017.11.013. 
